\title{
INFLUENCE OF DAILY SUCKING FREQUENCY ON THE CONSUMPTION OF LIQUID DIET IN EARLY-WEANED PIGLETS
}

\author{
A. HOLUB ${ }^{1}$ and F. DOLEŽEL ${ }^{2}$ \\ ${ }^{2}$ Veterinary Hospital, Jablunkovská 172, 73961 Tfinec
}

Received June 29, 1990

\begin{abstract}
Holub A., F. Doležel: Influence of Daily Sucking Frequency on the Consumption of Liquid Diet in Early-Weaned Piglets. Acta vet. Brno, 63, 1994: 121-128.

In 58 Large White piglets weaned on the second day after birth and reared individually in two groups in a thermoneutral zone on a liquid $78.47 \%$ dehydrated diet of a macronutrient content similar to that of sows' milk the consumption of the liquid diet, gross energy (GE), water, $N$ substances and lipids was measured up to 4 weeks of age.

One group was offered the diet for sucking 10 times a day at 2-hour intervals and the other group, 6 times a day at 3-hour intervals.

The consumption of diet, BE, water and macronutrients was high in all piglets. There were no significant differences in sucked meal size between the two groups fed at different frequency, except at the end of the 4th postnatal week. However, when related to live body mass or metabolic mass, the meal size was significantly $(P<0.05)$ greater in less frequently fed piglets between 5 and $7 \mathrm{~d}$ and from $12 \mathrm{~d}$ onwards. Nevertheless, the daily ingestion of the diet and its components by less frequently sucking piglets was lower. Related to live body mass and metabolic mass, the daily ingestion of the diet by these animals was lower only up to $13 \mathrm{~d}$. Afterwards this difference disappeared; from $14 \mathrm{~d}$ the piglets were able to compensate effectively for the limited frequency of contact with food.

It is concluded that the control of high consumption of food in piglets kept in isolation changes at the end of the second postnatal week, i. e., in the weaning period, in that the role of short-term local conditions in the gastrointestinal tract begins all at once be overlapped by long-term control mechanisms reflecting the metabolic situation of the individual more accurately.
\end{abstract}

Postnatal changes, meal size, daily consumption of energy, water, proteins and lipids.

In mammals, signals from the gastrointestinal tract play a primary role in postprandial satiety. They determine the meal size if food is available ad libitum (Smith and Gibbs 1979, Houpt 1982). These short-term mechanisms, however, obviously correlate with long-term mechanisms, e. g. with diurnal mechanisms (B ooth 1972). In pigs this is evidenced by the fact that intragastric administration of a diet decreases its oral intake during 24 hours (Pekas 1983, Gregory et al. 1989).

The situation in piglets during the early postnatal period is different in this respect. After intragastric infusions or nutritional deprivations they also show different prandial adaptations (Houpt et al. 1979). Therefore the distention of the various compartments of the gastrointestinal tract is not the only factor underlying their ingestion (Stephens 1975). Nevertheless, compared with those of grown-up pigs, their control mechanisms of food consumption are immature, gaining in functional efficacy only with uncreasing age (Holub 1962, 1968, 1982, 1988, 1990, 1991, 1994; Houpt et al. 1977, Stephens 1975, Wangsness and Soroka 1978, Gregory and Rayner 1987).

Up to now the maturation of short-term control mechanisms and their relation to the long-term control of diet, energy, macronutrients and water intake in piglets has been studied only partially, being overlapped by the interaction between dam and littermates (Holub 1994). The following experiment was designed to provide further information along this line.

\section{Materials and Methods}

A total of 58 Large White piglets divided into two groups were used to assess their consumption of diet, gross energy (GE), water, proteins and lipids. They were separated from the sows on the second day after birth and reared individually in cages as described previously (Holub 1964, 1988, 1990, 1991, Holub and Baranyiová 1989, Holub and Komárek 1964). They were fed a liquid diet (Holub 1963) which after heating to body temperature was offered to them for sucking ad libitum from feeding bottles ten times a day at 2-hour intervals except a 6-hour night break (Group A) and six times a day at 3-hour intervals except a night break of 9 hours (Group B). Its consumption was measured by weighing the bottles before and after sucking. The composition of the diet in the two groups was the same: it contained $5.36 \mathrm{MJ} . \mathrm{kg}^{-1} \mathrm{GE}$, half of this in lipids, $4.95 \%$ crude protein, $6.78 \%$ lipids, $8.59 \%$ saccharides and $78.47 \%$ water; thus it contained $146 \mathrm{~g}$ water per $1 \mathrm{MJ}$ BE and $16 \mathrm{~g}$ water per $1 \mathrm{~g}$ protein. Live body mass of the piglets was recorded daily before the first sucking. Their relative growth was expres- 
sed according to Brody (1945). The significance of the results was assessed by Student's t-test and their variability was expressed in terms of standard errors of the means.

\section{Results}

Intake of Diet, GE, Water and Macronutrients at One Sucking

In both groups of piglets the mean meal size of diet, GE, water, crude protein and lipids consumed at one sucking increased with advancing age in parallel between 3 and $28 \mathrm{~d} ; 5.7$ times in Group A and 6.3 times in Group B. The differences between the two groups were not significant except in the last two days of the experiment when the mean meal size was greater in Group $\mathrm{B}(\mathrm{P}<0.05)$ (Fig. 1).

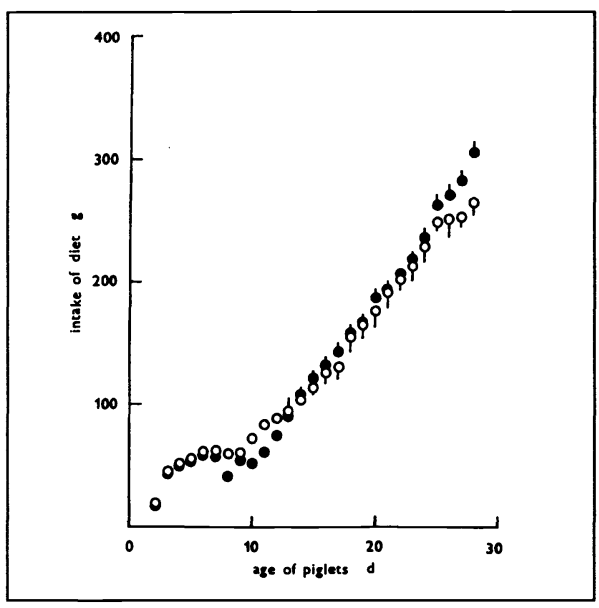

Fig. 1. Consumption of liquid diet at one sucking by piglets weaned on the second day after birth and fed 10 times (o) or six times (๑) a day during the first 4 postnatal weeks.

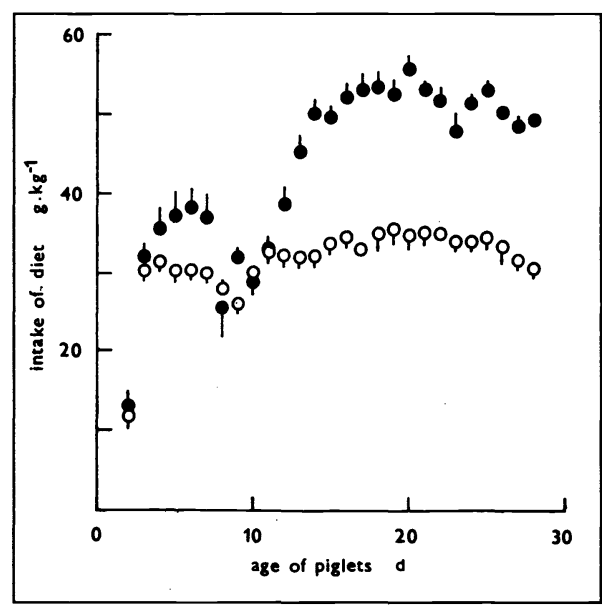

Fig. 2. Consumption of liquid diet per live body mass unit at one sucking by piglets weaned on the second day after birth and fed 10 times (o) or 6 times ( $\bullet$ ) a day during the first 4 postnatal weeks.

Expressed per live body mass unit, the consumption of diet, GE, water, protein and lipids was significantly higher $(\mathrm{P}<0.05)$ in Group $\mathrm{B}$ than in Group A between 5 and $7 \mathrm{~d}$ and from $12 \mathrm{~d}$ onwards (Fig. 2).

The differences became even more pronounced when the results were related to metabolic mass $\left(\mathrm{kg}^{0.75}\right)$ of the piglets (Fig. 3).

\section{Daily Consumption of Diet, GE, Water and Macronutrients}

In both groups the daily consumption of all fed components increased step by step, rising 5.9 times in Group A and as many as 7.3 times in Group B between 3 and $28 \mathrm{~d}$. Nevertheless, it was significantly $(P<0.01)$ lower in Group B than in Group A (Fig. 4).

Cumulative consumption of the diet and its components was also lower in Group B, by approximately $40 \%$, i. e. in proportion to the limited frequency at which the diet was offered (Table 1).

Live body mass of piglets of the two groups differed already at their inclusion in the experiment and rose uneqally during the experiment. Relative growth reached 142 in Group A (increase in live body mass by $5.88 \mathrm{~kg}$ ) and 133 in Group B (increase by $5.32 \mathrm{~kg}$ ). In consequence, piglets of Group B weighed $2.29 \mathrm{~kg}$ less than those of Group A at the end of the experiment (Fig. 5). Related to live body mass gain, the consumption of the diet was higher in Group A than in Group B (Table 1). 


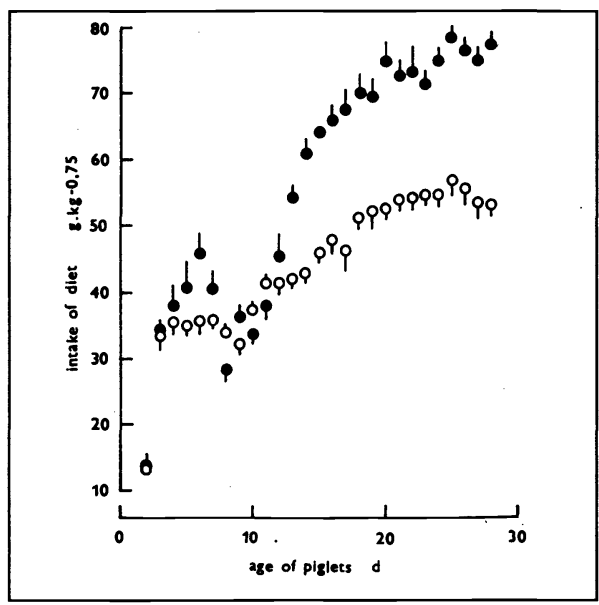

Fig. 3. Consumption of liquid diet per metabolic mass $\left(\mathrm{kg}^{0.75}\right)$ at one sucking by piglets weaned on the second day after birth and fed 10 times (0) or 6 times (•) a day during the first 4 postnatal weeks.

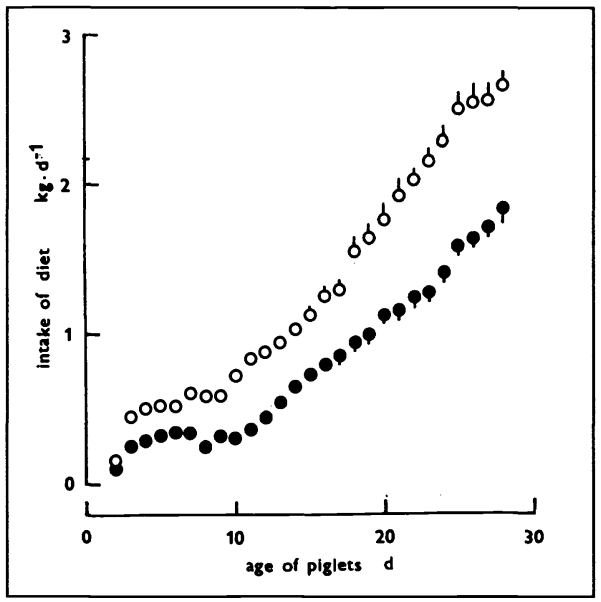

Fig. 4. Daily consumption of liquid diet by piglets weaned on the second day after birth and fed 10 times (o) or 6 times (๑) a day during the first 4 postnatal weeks.

To eliminate the differences due to the changes in body size of the piglets we expressed the consumption of the diet per live body mass unit. In Group A the daily consumption of diet, GE, water and $\mathrm{N}$ substances and lipids declined, after a preceding short period of adaptation to the new feeding technology, from 4 to $9 \mathrm{~d}$, then rose abruptly up to $19 \mathrm{~d}$ and after non--significant fluctuations declined from 25 to $28 \mathrm{~d}$. In Group B a similar time course of changes in the consumption was recorded. After a short adaptation period the consumption decreased from 6 to $8 \mathrm{~d}$, rose up to $20 \mathrm{~d}$ and declined to $27 \mathrm{~d}$. In Group A it was significantly higher than in Group B up to $13 \mathrm{~d}$. Afterwards this difference disappeared. Piglets that were offered the diet at 3 -hour intervals consumed at one sucking significantly $(\mathrm{P}<0.05)$ more diet per live body mass unit already from 5 to $7 \mathrm{~d}$. However, this apparently was not enough to counterbalance the food intake of piglets sucking at 2-hour intervals. This did not occur until the the decline in ingestion was overcome at about $9 \mathrm{~d}$; from $12 \mathrm{~d}$ onwards Group A piglets consumed significantly $(\mathrm{P}<0.05)$ more diet per live body mass unit till the end of the experiment (Tables 2 and 3 ).

Table 1

Consumption of liquid diet, BE, water, proteins and lipids by piglets weaned on the second day after birth and fed 10 times (A) or 6 times (B) a day during the first 4 postnatal weeks

\begin{tabular}{|lrrrr|r|}
\hline & & & Consumption & \multicolumn{2}{c|}{ per live body mass gain } \\
& A & Cumulated & \multicolumn{1}{c|}{ B } & \multicolumn{1}{c|}{ B } \\
\hline Diet & 35.7 & 21.2 & 6.1 & 4.1 \\
BE & 191.1 & 117.0 & 4.5 & 3.0 \\
Water & 28.0 & 17.1 & 300.0 & 203.0 \\
Proteins & 1.8 & 1.1 & 410.0 & 278.0 \\
Lipids & 2.4 & 1.5 & & \\
\hline
\end{tabular}

Note: Consumption of diet and water in $\mathrm{kg}$, of $\mathrm{BE}$ in $\mathrm{MJ}$ and of proteins and lipids in $\mathrm{g}$.

These differences in the consumption of diet, GE, water, protein and lipids became even more pronounced when related to metabolic mass. In Group B the consumption of nutrients was significantly lower by at least $12 \%(17 \mathrm{~d})$ and even by as many as $51 \%(8 \mathrm{~d})$ (Fig. 6). 
Table 2.

Daily consumption of liquid diet, BE and water per live body mass by piglets weaned on the second day after birth and fed 10 times (A) or 6 times (B) a day during the first 4 postnatal weeks

\begin{tabular}{|c|c|c|c|c|c|c|}
\hline \multirow[t]{2}{*}{ d } & \multicolumn{2}{|c|}{ Diet (\% live b. m.) } & \multicolumn{2}{|c|}{ BE (MJ.kg-1 live b. m.) } & \multicolumn{2}{|c|}{ Water (\% live b. m.) } \\
\hline & A & $\mathbf{B}$ & A & $\mathbf{B}$ & $\mathbf{A}$ & $\mathbf{B}$ \\
\hline $\begin{array}{r}2 \\
3 \\
4 \\
5 \\
6 \\
7 \\
8 \\
9 \\
10 \\
11 \\
12 \\
13 \\
14 \\
15 \\
16 \\
17 \\
18 \\
19 \\
20 \\
21 \\
22 \\
23 \\
24 \\
25 \\
26 \\
27 \\
28\end{array}$ & $\begin{array}{l}11.8 \pm 1.4 \\
30.3 \pm 1.4 \\
31.4 \pm 0.8 \\
30.3 \pm 1.1 \\
30.5 \pm 1.0 \\
30.0 \pm 1.1 \\
28.0 \pm 1.1 \\
26.1 \pm 1.1 \\
30.0 \pm 1.2 \\
32.7 \pm 1.0 \\
32.4 \pm 1.0 \\
32.0 \pm 1.2 \\
32.2 \pm 1.0 \\
33.9 \pm 1.3 \\
34.6 \pm 1.6 \\
33.0 \pm 1.4 \\
35.4 \pm 2.3 \\
35.6 \pm 1.6 \\
35.1 \pm 1.8 \\
35.4 \pm 2.0 \\
35.0 \pm 1.2 \\
34.7 \pm 1.5 \\
34.0 \pm 1.5 \\
34.8 \pm 1.6 \\
33.5 \pm 1.8 \\
31.9 \pm 1.0 \\
31.1 \pm 1,1\end{array}$ & $\begin{array}{r}7.7 \pm 0.9 \\
18.9 \pm 0.9 \\
21.1 \pm 1.6 \\
22.3 \pm 1.9 \\
23.0 \pm 1.9 \\
21.8 \pm 1.8 \\
14.9 \pm 1.0 \\
19.1 \pm 0.8 \\
12.8 \pm 1.0 \\
19.6 \pm 1.4 \\
23.2 \pm 1.7 \\
25.7 \pm 1.4 \\
30.0 \pm 1.5 \\
30.9 \pm 1.3 \\
31.3 \pm 1.6 \\
31.6 \pm 1.5 \\
32.0 \pm 1.4 \\
31.3 \pm 1.5 \\
33.2 \pm 1.2 \\
31.5 \pm 1.8 \\
31.1 \pm 1.2 \\
29.8 \pm 1.1 \\
30.6 \pm 1.1 \\
31.6 \pm 0.9 \\
30.1 \pm 0.9 \\
29.0 \pm 0.7 \\
29.5 \pm 0.8\end{array}$ & $\begin{array}{l}0.63 \pm 0.07 \\
1.62 \pm 0.07 \\
1.68 \pm 0.04 \\
1.62 \pm 0.06 \\
1.63 \pm 0.05 \\
1.61 \pm 0.06 \\
1.50 \pm 0.06 \\
1.40 \pm 0.06 \\
1.61 \pm 0.06 \\
1.75 \pm 0.05 \\
1.74 \pm 0.05 \\
1.71 \pm 0.06 \\
1.72 \pm 0.05 \\
1.82 \pm 0.07 \\
1.85 \pm 0.09 \\
1.77 \pm 0.07 \\
1.90 \pm 0.12 \\
1.91 \pm 0.09 \\
1.88 \pm 0.10 \\
1.90 \pm 0.11 \\
1.87 \pm 0.06 \\
1.86 \pm 0.08 \\
1.82 \pm 0.08 \\
1.86 \pm 0.09 \\
1.79 \pm 0.10 \\
1.71 \pm 0.05 \\
1.67 \pm 0.06\end{array}$ & $\begin{array}{l}0.41 \pm 0.05 \\
1.01 \pm 0.05 \\
1.13 \pm 0.09 \\
1.20 \pm 0.10 \\
1.23 \pm 0.10 \\
1.17 \pm 0.10 \\
0.80 \pm 0.05 \\
1.02 \pm 0.04 \\
0.93 \pm 0.05 \\
1.05 \pm 0.08 \\
1.24 \pm 0.09 \\
1.38 \pm 0.08 \\
1.61 \pm 0.08 \\
1.66 \pm 0.07 \\
1.68 \pm 0.09 \\
1.69 \pm 0.08 \\
1.72 \pm 0.08 \\
1.68 \pm 0.08 \\
1.78 \pm 0.06 \\
1.69 \pm 0.10 \\
1.67 \pm 0.06 \\
1.60 \pm 0.06 \\
1.64 \pm 0.06 \\
1.69 \pm 0.05 \\
1.61 \pm 0.05 \\
1.55 \pm 0.04 \\
1.58 \pm 0.04\end{array}$ & $\begin{array}{r}9.2 \pm 1.1 \\
23.8 \pm 1.1 \\
24.7 \pm 0.6 \\
23.8 \pm 0.9 \\
27.0 \pm 0.7 \\
23.5 \pm 0.8 \\
22.0 \pm 0.8 \\
20.5 \pm 0.8 \\
23.5 \pm 0.9 \\
25.6 \pm 0.8 \\
25.4 \pm 0.8 \\
25.1 \pm 1.1 \\
25.3 \pm 0.8 \\
26.6 \pm 1.0 \\
27.2 \pm 1.3 \\
25.9 \pm 1.1 \\
27.8 \pm 1.8 \\
27.9 \pm 1.3 \\
27.6 \pm 1.4 \\
27.7 \pm 1.6 \\
27.5 \pm 1.0 \\
26.9 \pm 1.2 \\
26.7 \pm 1.2 \\
27.4 \pm 1.3 \\
26.3 \pm 1.4 \\
25.0 \pm 0.8 \\
24.4 \pm 0.9\end{array}$ & $\begin{array}{r}6.0 \pm 0.7 \\
14.8 \pm 0.7 \\
16.6 \pm 1.3 \\
12.5 \pm 1.5 \\
18.0 \pm 1.5 \\
17.9 \pm 1.4 \\
11.7 \pm 0.8 \\
15.0 \pm 0.6 \\
14.0 \pm 0.8 \\
15.8 \pm 1.1 \\
18.2 \pm 1.3 \\
20.2 \pm 1.1 \\
23.5 \pm 1.2 \\
24.2 \pm 1.0 \\
24.6 \pm 1.3 \\
24.8 \pm 1.2 \\
25.1 \pm 1.1 \\
24.6 \pm 1.2 \\
26.1 \pm 0.9 \\
26.7 \pm 1.4 \\
24.4 \pm 0.9 \\
23.4 \pm 0.9 \\
24.0 \pm 0.9 \\
24.8 \pm 0.7 \\
23.6 \pm 0.7 \\
22.8 \pm 0.5 \\
23.1 \pm 0.6\end{array}$ \\
\hline
\end{tabular}

\section{Discussion}

In mammals oral nutrition associated with activation of specific functions of the gastrointestinal tract begins in the perinatal period. Like other neonates, piglets begin to cover their nutritional needs by sucking milk in complex interactions between the sow and littermates. The ritual of collective sucking associated inseparably with satisfaction of the nutritional and hydration needs as component units of the higher biological unit made up by the litter and sow is rapid to develop. The feeding mechanisms of neonatal piglets are so specific in character (Adolph 1968. Holub 1968, 1988, 1990, 1991, 1994; Phifer and Hall 1988) that the meaning of terms such as hunger, thirst and satiety is different than in grown-up pigs. Their consumption can be limited by both the sow and competitive littermates. In piglets left with the sow the transition from this early suckling control of nutrition to a more mature and more plastic one does not begin until they not only suck milk but also begin take in solid feeds and drink liquids individually (Holub 1968, 1988, 1990, 1991, 1994). The regulation of ingestion depending hitherto on the sow plus competitive littermates is thus shifted to the individual piglet. The new hierarchy of regulation arising in the piglet makes it capable of separate and appropriately integrated nutritional responses even after isolation from the sow.

However, if a piglet is weaned on the second day after birth onto a liquid diet of a constant energy, macronutrient and water content fed ad libitum at the same intervals for four weeks, it gets abruptly into a quite different situation. Its world, environment and stimuli are changed completely whithin 48 hours after birth. The developing intricate and fragile biological system, sow plus litter, is thus disrupted and demolished. The piglet is transferred from common nutrition with marked competitive elements in the litter to solitary nutrition (Holub 1994). It is not limited by sow's milk production and does not compete for milk with its littermates any longer. However, it can neither select the kind of nutrition nor change the frequency of its consumption (Holub 1988, 1990, 1991, 1994). After sucking a certain volume of diet and a certain amount of energy, macronutrients and water it stops its ingestion by itself. 


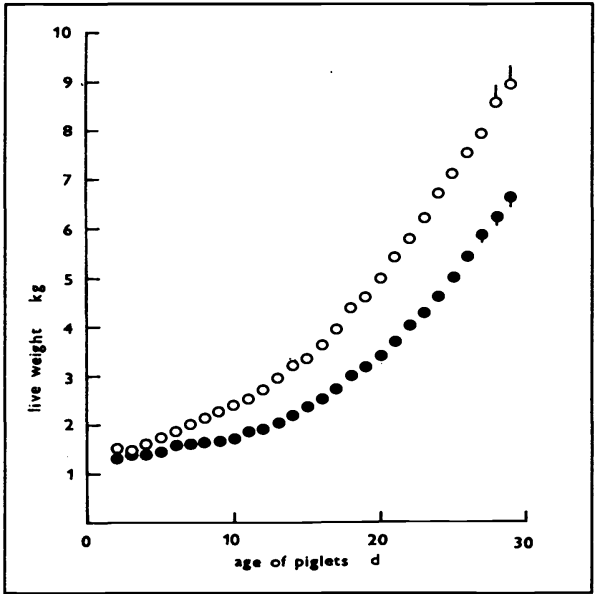

Fig. 5. Daily changes in live body mass of piglets weaned on the second day after birth and fed 10 times (O) or 6 times $(\bullet)$ a day during the first 4 postnatal weeks.

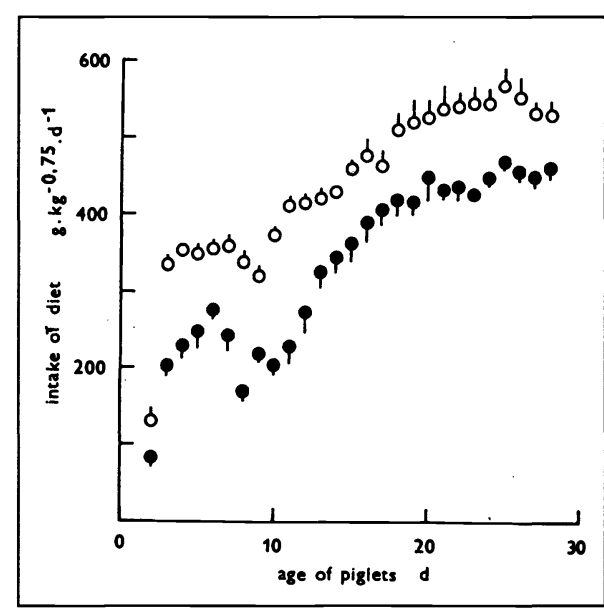

Fig. 6. Daily consumption of liquid diet per metabolic mass $\left(\mathrm{kg}^{0.75}\right)$ by piglets weaned on the second day after birth and fed 10 times $(O)$ or 6 times $(\bullet)$ a day during the first 4 postnatal weeks.

By this intervention the large relative daily ingestion, characteristic of piglets sucking only sow's milk in the first three postnatal weeks (Holub 1962), is made to continue in further days (Holub 1964, 1988, 1990, 1991, 1994, Holub and Ko márek 1964). The high daily consumption of diet, GE, water, crude protein and lipids per live body mass unit by piglets fed 10 times a day in the present experiment is in keeping with the fore-going observations and confirms them.

The same applies to experiments where piglets were in contact with nutrition only nine times a day using the same weaning technique (Holub 1968, Holub and Baranyiova 1989).

No significant differences were previously found in the volume of diet ingested at one sucking at various daily hours in piglets offered the diet for sucking 10 times a day (Holub and Komárek 1964). This averaged one tenth of daily consumption throughout the experimental period. That such differences are not significant was our premise in the experiment with piglets sucking 6 times a day at intervals prolonged from 2 to 3 hours.

In our present experiment the actual mean meal size increased without showing significant differences between Groups A and B except in the last two days of the fourth postnatal week. However, when the results were related to live body mass and metabolic mass, a different picture became apparent: piglets of Group B ingested significantly more diet at one sucking than of those Group A from 5 to $7 \mathrm{~d}$ and then from $12 \mathrm{~d}$ till the end of the experiment. Nevertheless, it was not until the end of the second postnatal week that the meal size of Group B piglets became so great that full compensation for the limited contact with the diet was achieved. From this age the daily intake of the diet and its components by piglets fed 6 times a day was the same as in those fed 10 times a day, a preliminary observation along this line being reported by us previously (Holub and Doležel 1964).

The ingested volume is determined primarily by stimuli from the gastrointestinal tract, by local situation in the stomach. The consequence of their short-term action was that the meal size made up about $70 \%$ of the gastric volume found in previous report (Ježková and Holub 1969) on the basis of post-mortem examination. Another factor involved in the available capacity of the stomach is the passage of food through the gastrointestinal tract. In piglets it takes place so rapidly during the postnatal period that at minimally 2-hour ingestion intervals it cannot be regarded as a limiting factor.

However, the short-term mechanisms underlying food intake are obviously not the only 
Table 3

Daily consumption of proteins and lipids per live body mass by piglets weaned on the second day after birth and fed 10 times (A) or 6 times (B) a day during the first 4 postnatal weeks.

\begin{tabular}{|c|c|c|c|c|c|}
\hline \multirow[t]{2}{*}{ d } & & Proteins & (g.kg-1 live b. m.) & Lipids & (g.kg-1 live b. m.) \\
\hline & & A & B & A & B \\
\hline $\begin{array}{r}2 \\
3 \\
4 \\
5 \\
6 \\
7 \\
8 \\
9 \\
10 \\
11 \\
12 \\
13 \\
14 \\
15 \\
16 \\
17 \\
18 \\
19 \\
20 \\
21 \\
22 \\
23 \\
24 \\
25 \\
26 \\
27 \\
28\end{array}$ & ' & $\begin{array}{r}5.8 \pm 0.7 \\
15.0 \pm 0.7 \\
15.5 \pm 0.4 \\
15.0 \pm 0.5 \\
15.1 \pm 0.5 \\
14.9 \pm 0.5 \\
13.9 \pm 0.5 \\
12.9 \pm 0.5 \\
14.9 \pm 0.6 \\
16.2 \pm 0.5 \\
16.0 \pm 0.5 \\
15.8 \pm 0.6 \\
15.9 \pm 0.5 \\
16.8 \pm 0.6 \\
17.1 \pm 0.8 \\
16.3 \pm 0.7 \\
17.5 \pm 1.1 \\
17.6 \pm 0.8 \\
17.4 \pm 0.9 \\
17.5 \pm 1.0 \\
17.3 \pm 0.6 \\
17.2 \pm 0.7 \\
16.8 \pm 0.7 \\
16.6 \pm 0.8 \\
16.6 \pm 0.9 \\
15.8 \pm 0.5 \\
15.4 \pm 0.5\end{array}$ & $\begin{array}{r}3.8 \pm 0.4 \\
9.4 \pm 0.4 \\
10.4 \pm 0.8 \\
11.0 \pm 0.9 \\
11.4 \pm 0.9 \\
10.8 \pm 0.9 \\
7.4 \pm 0.5 \\
9.5 \pm 0.4 \\
8.8 \pm 0.5 \\
9.7 \pm 0.7 \\
11.5 \pm 0.8 \\
12.7 \pm 0.8 \\
14.9 \pm 0.7 \\
15.3 \pm 0.6 \\
15.5 \pm 0.8 \\
15.6 \pm 0.7 \\
15.8 \pm 0.7 \\
15.5 \pm 0.7 \\
16.4 \pm 0.6 \\
15.6 \pm 0.9 \\
15.4 \pm 0.6 \\
14.8 \pm 0.5 \\
15.1 \pm 0.5 \\
15.6 \pm 0.4 \\
14.9 \pm 0.4 \\
14.4 \pm 0.3 \\
14.6 \pm 0.4\end{array}$ & $\begin{array}{r}8.0 \pm 0.9 \\
20.5 \pm 0.9 \\
21.3 \pm 0.5 \\
20.5 \pm 0.7 \\
20.7 \pm 0.7 \\
20.3 \pm 0.7 \\
19.0 \pm 0.7 \\
17.7 \pm 0.7 \\
20.3 \pm 0.8 \\
22.2 \pm 0.7 \\
22.0 \pm 0.7 \\
21.7 \pm 0.8 \\
21.8 \pm 0.7 \\
23.0 \pm 0.9 \\
23.5 \pm 1.1 \\
22.4 \pm 0.9 \\
24.0 \pm 1.6 \\
24.1 \pm 1.1 \\
23.8 \pm 1.2 \\
24.0 \pm 1.4 \\
23.7 \pm 0.8 \\
23.5 \pm 1.0 \\
23.1 \pm 1.0 \\
22.7 \pm 1.1 \\
22.7 \pm 1.2 \\
21.6 \pm 0.7 \\
21.1 \pm 0.7\end{array}$ & $\begin{array}{r}5.2 \pm 0.6 \\
12.8 \pm 0.6 \\
14.3 \pm 1.1 \\
15.1 \pm 1.3 \\
15.6 \pm 1.3 \\
14.8 \pm 1.2 \\
10.1 \pm 0.7 \\
12.9 \pm 0.9 \\
12.1 \pm 0.7 \\
13.3 \pm 0.9 \\
15.7 \pm 1.2 \\
17.4 \pm 0.9 \\
20.3 \pm 1.0 \\
21.0 \pm 0.9 \\
21.2 \pm 1.1 \\
21.4 \pm 1.0 \\
21.7 \pm 0.9 \\
21.2 \pm 1.0 \\
22.5 \pm 0.8 \\
21.4 \pm 1.2 \\
21.1 \pm 0.8 \\
20.2 \pm 0.7 \\
20.7 \pm 0.7 \\
21.4 \pm 0.6 \\
20.4 \pm 0.6 \\
19.7 \pm 0.5 \\
20.0 \pm 0.5\end{array}$ \\
\hline
\end{tabular}

ones even in the first postnatal week (Houpt et al. 1979). Also from our present results it appears that specific long-term mechanisms, too, begin to be increasingly involved during this period. They gain in importance with advancing age (S tephen s 1975, Houpt et al. 1977) and as evident from our results obtained under the present experimental design, where the consumption of liquid diet fed at different frequencies was measured both at one sucking and daily, specific long-term mechanisms become all at once dominant, beginning to overlap those of short-term operation. In piglets this occurs at the end of the second postnatal week, during a period characterized by us as the weaning period (Holu b 1968). Their appetitive responses gain gradually in accuracy, become differentiated and more deliberate even without participation of the dam (Hol ub 1994). In the interest of modifications in the metabolism which also goes through intensive individual development the postnatal supply of nutrients in piglets, similarly to other polytocous species (Adolph 1968, Hall 1979, 1990), undergoes continuous improvement, becoming considerably plastic (Holub 1994) even in diarrhoeic piglets (Baranyiová and Holub 1991, 1993ab). Thus when subjected to social deprivation (separation from both the dam and littermates) and experiencing deep interventions in their very intensive and energetically tense nutritional regimen, piglets are able to modify homeostasis and remain in anabolism even higher than that exhibited by piglets reared traditionally with the dam in the litter.

The afore-mentioned facts provide further evidence to substantiate our previous generalization (Hol u b 1968) that early postnatal development of piglets goes through several stages in a cascade-like way.

\section{Vliv denní frekvence sání na konzum tekuté diety u časně odstavených selat}

U 58 selat plemene bílého ušlechtilého odstavených ve druhém dnu života po narození a individuálně odchovávaných ve dvou skupinách $\mathrm{v}$ termoneutrální zóně na tekuté dietě hydratované ze 78,47 \% a obsahem makronutrientů podobné mléku prasnic jsme do stárí 4 týdnů měrili konzum tekuté diety, bruttoenergie (BE), vody, $\mathrm{N}$ látek a tukủ. 
První skupině jsme nabízeli dietu $\mathrm{k}$ sání desetkrát denně ve dvouhodinových intervalech, druhé šestkrát denně $\mathrm{v}$ tř́hodinových intervalech.

Konzum diety, BE, vody a makronutrientủ byl u všech selat vysoký. Ve velikosti sané porce jsme mezi rủzně frekventně živenými selaty, až na konec čtvrtého týdne života, prưkazné rozdíly nezjistili. Na živou či metabolickou hmotnost však jedinci méně frekventně živení sáli 5. až 7. a od 12. dne průkazně větší porce. Celodenní ingesce diety a jejích komponent však byla u skupiny selat méně casto sajících nižší. Na živou a metabolickou hmotnost tomu bylo jen do 13. dne. Potom tento rozdíl zanikl a selata byla od 14. dne s to omezení častosti kontaktu s potravou úcinně kompenzovat.

$Z$ uvedeného vyplývá, že se rízení vysokého konzumu potravy selat chovaných izolovaně na konci druhého týdne po narození, tedy v údobí odstavu, mění, a to tak, že význam krátkodobých lokálních poměrủ v gastrointestinálním traktu počíná být náhle, kaskádovitě, překrýván dlouhodobými regulačními mechanizmy, odrážejícími metabolickou situaci jedince přesněji.

\section{Влияниө суточной частоты подсоса на потрөблөниө жидкой диөты у ранних отъөмышөй}

У 58 поросят белого породного племена, отнимаемых на вторые сутки после рождения и индивидуально содержимых двумя группами в термонейтральной зоне на жидкой диете, гидратированной в 78,47 \% содержанием макронутриентов, похожем на молоко свиноматок, до возраста 4 недель нами проводились измерения жидкой диеты; общей энергии (BE), воды, азотосодержащих веществ и жиров.

Первая группа сосала диету десять раз в сутки в двухчасовых промежутках, вторая - шесть раз в сутки в трехчасовых интервалах.

Потребление диеты, ВЕ, воды и макронутриентов было высокое у всех поросят. В объемай потребляемых порций разной частотой питаемый поросят до самого конца четвертой недели жизни нами не было установлено существенной разницы. Однако отдельные менее часто питаемые поросята на живую или метаболическую массу сосали на 5-7 сутки и с 12 суток порции существенно больше. Суточный прием пищи и ее компонентов был однако у группы менее часто питаемых поросят ниже. К живой или метаболической массе это имело место лишь до 13 суток. После этого упомянутая разница исчезает и, начиная с 14 суток, поросята были в состоянии компенсировать ограничение частоты контакта с пищей.

Из сказанного вытекает, что управление высокого потребления пищи изолированно содержимыхпоросят к концу второй недели после рождения, следовательно, в период отьема, меняется именно так, что значение краткосрочной местной ситуации в желудочно-кишечном тракте вдруг каскадно перекрывается длительными регуляторными механизмами, отражающими точное метаболическую ситуацию особи.

\section{References}

ADOLPH, E. F.: Origins of physiological regulations. New York-London 1968. 147 p.

BARANYIOVÁ, E.-HOLUB, A.: Scouring piglets and their feeding behaviour. In: Proceedings of the 7th International Congress on Animal Hygiene. Vol. III. Leipzig 1991. p. 1090-1094

BARANYIOVA, E.-HOLUB, A.: Effect of diarrhoea on water consumption of piglets weaned on the first day after birth. Acta vet. Brno, 62, 1993a: 27-32

BARANYIOVA E,-HOLUB A: The effects of diarrhoea on food intake of piglets weaned on the day of birth. Vet. Med.-Praha 38, 1993b, 659-665 
BOOTH, D. A.: Postabsorptively induced suppresion of appetite and the energostatic control of feeding. Physiol. Behav., 9, 1972: 199-202

BRODY, S.: Bioenergetics and growth. New York 1945. 1023 p.

GREGORY, P. C.-McFAYDEN, M.-RAYNER, D. V.: Relation between gastric emptying and short-term regulation of food intake in the pig. Physiol. Behav., 45, 1989: 677-683

GREGORY, P. C.-RAYNER, D. V.: The influence of gastrointestinal infusion of fats on regulation of food intake in pigs. J. Physiol., 385, 1987: 471-481

HALL, W. G.: Feeding and behavioral activation in infant rats. Science, 190, 1979: 1313-1315

HALL, W. G.: The ontogeny of ingestive behavior. In: Handbook of behavioral neurobiology. Volume 10. Neurobiology of food and fluid intake. New York-London 1990. p. 77-123

HOLUB, A.: Kvantitativní poměry ve výživě selat v době sání. Vet. Med. Praha, 7(35), 1962: 711-724

HOLUB, A.: Semisyntetická vysokokalorická dieta pro selata uměle odchovávaná od druhého dne života. Vet. Med. Praha, 8(36), 1963: 427-430

HOLUB, A.: Váhové płírústky selat chovaných na semisyntetické vysokokalorické dietě v prvním měsíci života. Živoč. Výroba, 9(37), 1964: 539-544

HOLUB, A. Funkění periodizace Casného postnatálního vývoje u selat. Brno 1968. 125 p.

HOLUB, A.: Functional development and food intake of piglets. Acta vet. Brno, Suppl. 5, 1982: 5-12

HOLUB, A.: Postnatale Änderungen im Nahrungsaufnahmeverhalten von Ferkeln. Mh. Vet. Med., 43, 1988: $857-860$

HOLUB, A.: Effect of rearing practices on the water consumption by piglets in the first eight weeks after birth. Acta vet. Brno, 59, 1990: 129-137

HOLUB, A.: Konzum vody selaty časně odstavovanými v rùzném věku na tekutou dietu. Vet. Med. Praha, 36, 1991: 415-422

HOLUB, A: Prasnice a selata-nutrǐní interakce. Vet. Med. Praha, 39, 1994: 117-132

HOLUB, A.-BARANYIOVÁ, E.: Radiačně ošetřená mléčná krmná směs ve výživě casně odstavených selat. Vet. Med. Praha, 34, 1989: 545-552

HOLUB, A.-DOLEŽEL, F.: Vývoj selat odstavených druhého dne života. IX. Vliv frekvence podávání diety na její konzum a na váhové płírustky selat v prvých čtył̌ech týdnech života. Čs. Fysiol., 13, 1964: 247-248

HOLUB, A.-KOMÁREK, J.: Vývoj selat odstavených druhého dne života. I. Konzum semisyntetické diety v prvých ctyřech týdnech života. Sb. VŠZ Brno B, 12(33), 1964: 75-81

HOUPT, K. A.: Gastrointestinal factors in hunger and satiety. Neurosci. Behav. Rev., 6, 1982: 145-164

HOUPT, K. A.-HOUPT, T. R.-POND, W. G.: Food intake controls in the suckling pig: glucoprivation and gastrointestinal factors. Amer. J. Physiol., 232, 1977: E510-E514

HOUPT, K. A.-HOUPT, T. R.-POND, W. G.: The pig as a model for the study of obesity and of control of food intake: A review. Yale J. Biol. Med., 52, 1979: 307-329

JEŽKOVÁ, D.-HOLUB, A.: Vliv vysokokalorické semisyntetické diety na délkové, váhové a objemové změny střev a objemové změny žaludku u selat v prvním měsíci života. Vet. Med. Praha, 14(42), 1969: 305-309

PEKAS, J. C.: A method for direct gastric feeding and the effect of voluntary ingestion in young swine. Appetite, 4, 1983: 23-30

PHIFER, C. B.-HALL, W. G.: Ingestive behavior in preweanling rats: emergence of postgastric control. Amer. J. Physiol., 255, 1988: R191-R199

SMITH, G. P.-GIBBS, J.: Postprandial satiety. In: Progress in psychobiology and physiological psychology. Vol. 8. New York 1979. p. 179-242

STEPHENS, D. B.: Effects of gastric loading on the suckling response and voluntary milk intake in neonatal pigs. J. Comp. Physiol. Psychol., 88, 1975: 796-805

WANGSNESS, P. J.-SOROKA, G. H.: Effect of energy concentration of milk on voluntary intake of lean and obese piglets. J. Nutr., 108, 1978: 595-600

Reprint requests:

A. Holub ${ }^{1}$,

Kolište 9

60200 Brno

Czech Republic 